\section{Mechanical Removal of Summer Dodder Infestations and Impacts on Cranberry Yield}

\author{
Laura K. Hunsberger ${ }^{1}$, Wesley R. Autio ${ }^{2}$, \\ Carolyn J. DeMoranville ${ }^{3}$, and Hilary A. Sandler ${ }^{3}$
}

ADDITIONAL INDEX WORDS. Cuscuta gronovii, Vaccinium macrocarpon, nonchemical weed management, IPM, parasitic weeds, raking

\begin{abstract}
SUMMARY. Over a 2-year period, 11 cranberry (Vaccinium macrocarpon) farms in southeastern Massachusetts were selected to evaluate mechanical removal of swamp dodder (Cuscuta gronovii) with a conventional hand-held bamboo rake. This technique consisted of breaking and removing large strands of the parasite that connected host plants; embedded and encircled portions of the parasite were not removed. Differences in dodder biomass, cranberry yield, and berry weight were determined in plots that received zero, one, or two weed-removal events. Removing dodder one time per season reduced percentage of weed cover by more than $74 \%$ in both years. Impacts on dodder fresh and dry weight were not as discernible. Removal initially decreased dodder biomass, which remained $20 \%$ to $40 \%$ lower than the baseline values, but removal treatments did not differ statistically from the control. No additional benefits were obtained by removing the weed cover more than once. Biomass per berry was not affected by mechanical weed removal and fruit of marketable size were produced in the treated area. Substantial yield loss was largely attributable to the dodder infestations, but multiple removals may eventually reduce yield to levels below those associated with infestations alone.
\end{abstract}

$\mathrm{D}$ odders (Cuscuta spp.) are obligate parasites that embed specialized structures (haustoria) in the vascular tissues of host plants to obtain carbohydrates and water. The parasite forms a dense mat of thin, yellow, twining stems around and between infected hosts. Severe infestations reduce the vigor of the host as well as prevent sunlight from reaching surviving plants and fruit underneath the mat of stem growth (Dawson et al., 1984). Swamp dodder is a severe weed problem for cranberries produced in Massachusetts and Wisconsin (Bewick et al., 1989; Devlin and Deubert, 1980). In commercial

${ }^{1}$ Maryland Cooperative Extension, Worcester County, P.O. 219, Snow Hill, MD 21863. This paper is a portion of a thesis submitted by the senior author in fulfilling Master's degree requirements. To whom reprint requests should be addressed; e-mail address: lhuns@umd.edu

${ }^{2}$ University of Massachusetts, Department of Plant, Soil, and Insect Sciences, Bowditch Hall, Amherst, MA 01002.

${ }^{3}$ UMass-Amherst Cranberry Station, P.O. Box 569 , East Wareham, MA 02538.

We acknowledge the excellent technical assistance of M. Cannon and L. Little. We also thank L. Briggs, Decas Cranberry Company, Edgewood Cranberry Trust, and Hiller Cranberry Company for use of their properties. The research was funded in part by Ocean Spray Cranberries, Inc., Lakeville-Middleboro, Mass., and Cape Cod Cranberry Growers' Association, East Wareham, Mass. production areas, it spreads rapidly, damages cranberry vines significantly, and can dramatically reduce yield (80\% to $100 \%$ ) (Bewick et al., 1989 ; Devlin and Deubert, 1980; Else et al., 1995).

Dichlobenil (Casoron; Crompton Uniroyal Chemical, Middlebury, Conn.) and pronamide (Kerb; Dow AgroSciences LLC, Indianapolis) are often employed for chemical control of dodder (Sandler, 2005). Nonchemical methods, such as the application of sand to the production surface (Sandler et al., 1997) and short-term floods (Sandler and Mason, 2004), can also control a portion of the emerging dodder population. However, all of these practices target the weed prior to emergence. Postemergence options are extremely limited. Dodder is such a severe problem that growers are willing to devote management time to remove attached dodder from individual hosts by hand. The removal of the stems has many benefits, including increased sunlight penetration into the canopy and the potential to reduce the overall number of seeds produced by the parasite (Else, 1990).

Mechanical or nonchemical removal of infestations can be used for dodder control in alfalfa (Medicago sativa). Burning and mowing are recommended cost-effective practices in alfalfa (Cudney et al., 1992); however, the crop also is reduced or sacrificed. In cranberry production, mowing around ditches and reservoirs and the use of preemergence herbicides to reduce the number of potential primary hosts for dodder are recommended practices (Dawson et al., 1984; Sandler, 2005). The removal of the parasite during the season by hand (very labor intensive) or during the postharvest flood (an easier practice involving the flotation and corralling of abscised cranberry leaves and debris, including dodder seedpods) might also help to minimize the spread of dodder within the farm. Decreased seed production may aid in the reduction of future dodder infestations on the production area.

Expansion of postemergence options for dodder management in cranberry is a critical need. The benefits of incorporating another tool, a handheld bamboo rake, into the integrated weed management plan for dodder had not been evaluated. The objectives of this study were to: 1) evaluate the efficacy of dodder control by mechanical removal with a conventional rake; 2 ) evaluate the impact of this nonchemical practice on cranberry yield; and 3 ) incorporate the results of the study into the standard recommendations for the integrated control of dodder in cranberry.

\section{Materials and methods}

Due to the patchy nature of dodder infestations, it was difficult to identify infestations of adequate size and uniformity that would have allowed the establishment of an ad-

\begin{tabular}{llll}
\hline $\begin{array}{l}\text { Units } \\
\text { To convert U.S. to SI, } \\
\text { multiply by }\end{array}$ & U.S. unit & SI unit & $\begin{array}{l}\text { To convert SI to U.S., } \\
\text { multiply by }\end{array}$ \\
\hline 0.0929 & $\mathrm{ft}^{2}$ & $\mathrm{~m}^{2}$ & 10.7639 \\
6.4516 & $\mathrm{inch}^{2}$ & $\mathrm{~cm}^{2}$ & 0.1550 \\
28.3495 & $\mathrm{oz}$ & $\mathrm{g}$ & 0.0353 \\
305.1517 & $\mathrm{Oz} / \mathrm{ft}^{2}$ & $\mathrm{~g} \cdot \mathrm{m}^{-2}$ & 0.0033 \\
2.2417 & ton $/ \mathrm{acre}$ & $\mathrm{t} \cdot \mathrm{ha}^{-1}$ & 0.4461 \\
$\left({ }^{\circ} \mathrm{F}-32\right) \div 1.8$ & ${ }^{\circ} \mathrm{F}$ & ${ }^{\circ} \mathrm{C}$ & $\left(1.8 \times{ }^{\circ} \mathrm{C}\right)+32$
\end{tabular}


equate number of replicates at one site. Thus, for the purposes of this study, infestations on several commercial cranberry farms in southeastern Massachusetts were identified during 1996 and 1997. Each farm was required to have dodder infestations that had not been previously disturbed or removed. In 1996 and 1997, six and five sites were used, respectively. A uniformly dodder-infested area was identified at each site. Before the infested area was subdivided into three $3-\mathrm{m}^{2}$ blocks, visual observations were made to confirm the homogeneity of the cranberry vine stand. Although quantitative percent cover measurements were not taken, plots were established in areas of uniform vine cover. The treatments were randomly applied to one $3-\mathrm{m}^{2}$ block. The treatments were: control (noweed removal), weed removal one time per season (11 July 1996 and 27 July 1997), and weed removal two times per season (as above and 30 July 1996 and 8 Aug. 1997).

Using a fan-shaped bamboo rake, removal of the dodder was not vigorous but was of adequate force to detach the dodder from the hosts. To minimize the variation in dodder removal technique, the same individual performed all treatments in both years. Although no guard ways were present between plots, efforts were made to confine foot traffic to the edges of the treated area. To further avoid foot traffic within treatments, samples were never collected from the edges of the plot. At each treatment date, one or two passes were made through each plot to remove the dodder population. The goal of mechanical removal was to achieve an open canopy, i.e., most of the major dodder strands between hosts (cranberry and/or weeds) were broken and removed and the leaves of the cranberry vine were more readily visible. The removal technique did not eradicate the dodder; no effort was made to remove embedded dodder or dodder strands that encircled the host. The exact number of passes used in each plot was determined based on visual examination of the treated area (using the "open canopy" criteria) after each pass with the bamboo rake.

In both years, the plots were evaluated visually for percent dodder cover before and after dodder removal. A final percent dodder cover evaluation was made on 15 Aug. 1996 and 28 Aug. 1997. Cover cannot be measured precisely and was placed in one of 10 categories (e.g., $0 \%$ to $10 \%, 11 \%$ to $20 \%, 21 \%$ to $30 \%$, etc.) by visual estimate (Barbour et al., 1987). Percent cover was evaluated by the same two individuals on all sampling dates. The observers recorded their estimations independently. Resolution of discrepancies (if separated by more than one group) was accomplished by taking the average between the estimations. Resolution of larger discrepancies was obtained by reevaluation.

Biomass (fresh and dry) was determined in 1997 only. Pretreatment biomass was determined by placing a $900-\mathrm{cm}^{2}$ quadrat randomly within each plot, avoiding the edges. Raking was simulated by the collectors dragging their fingers through the plot and gathering all detached dodder strands into a paper sample bag. No extra effort was made to remove any embedded or encircled dodder from the cranberry vines or other hosts. In a similar fashion, posttreatment biomass was determined immediately after the mechanical removal procedure was finished. Samples were placed in a cooler for transport. Removed dodder biomass was weighed immediately upon arrival at the laboratory, dried at $62{ }^{\circ} \mathrm{C}$ for 12 to $14 \mathrm{~h}$, and weighed again.

Fruit were collected in mid-Sept. 1997 by harvesting all berries within one randomly selected $900-\mathrm{cm}^{2}$ area in each replicate. In addition, one randomly selected noninfested area proximal to each block was harvested. Fruit samples were visually evaluated and any nonpollinated, aborted, or undersized fruit were discarded since they would not be collected during an actual harvest. The remaining fruit were counted and weighed (pooled sample). Berry weight was determined by dividing the pooled weight by the total number of fruit collected.

The experimental design was randomized complete block with the frequency of weed removal as the main effect. Multiple farms (with each treatment represented once at each site) were utilized in this study and, consequently, sites were treated as replicates. Analyses of variance were performed on percent cover, biomass, and yield data; and treatment differences were evaluated by Tukey's honestly significant difference test $(P=0.05)$ using SAS (version 8.2; SAS Institute, Cary, N.C.). Using the original replicated data, percent change estimates for percent cover (1996 and 1997) and fresh and dry biomass (1997 only) for each treatment were calculated by determining differences for the three parameters on the second and third sampling date compared to the baseline data (collected on the first date prior to removal).

\section{Results and discussion}

In both years, dodder cover was reduced $74 \%$ to $93 \%$, but no differences were seen between one and two weed removals per season (Tables 1-2). Although within each date, one removal appeared to reduce dodder fresh biomass (63\% to 75\%) and dry biomass $(56 \%$ to $66 \%)$, no statistical differences were seen (Table 2). When compared to the baseline status for each treatment, percent cover of untreated dodder increased slightly (1997) but percent cover after dodder removal remained constant in both years (Fig. 1). Biomass (dry and fresh weight) increased in the treated plots during the 1-month sampling period, but these plots still contained $20 \%$ and $40 \%$ less biomass, respectively, compared to the start of the study. In contrast, the untreated plots had a $60 \%$ increase in dry biomass. Weed removal in infested areas did not affect cranberry yield or biomass per berry (Table 3 ); however, yield in all infested plots was lower than

Table 1. 1996. Changes in percent dodder cover on infested cranberry vines prior to and following weed removal (raking) with a conventional bamboo hand rake $(\mathrm{N}=6)^{\mathrm{z}}$.

\begin{tabular}{|c|c|c|c|}
\hline \multirow[b]{3}{*}{ Treatment } & \multicolumn{3}{|c|}{ Sampling date } \\
\hline & 11 July & 30 July & \\
\hline & Post-raking & Post-raking & 15 Aug. \\
\hline
\end{tabular}

\begin{tabular}{lcrrrr}
\hline \multicolumn{7}{c}{ Weed cover (\%) } \\
Zero removals & $66 \mathrm{a}$ & $66 \mathrm{a}$ & $69 \mathrm{a}$ & $69 \mathrm{a}$ & $69 \mathrm{a}$ \\
One removal & $71 \mathrm{a}$ & $8 \mathrm{~b}$ & $10 \mathrm{~b}$ & $10 \mathrm{~b}$ & $10 \mathrm{~b}$ \\
Two removals & $70 \mathrm{a}$ & $7 \mathrm{~b}$ & $10 \mathrm{~b}$ & $5 \mathrm{~b}$ & $5 \mathrm{~b}$ \\
\hline${ }^{2}$ Mean separation within column by Tukey's honestly significant difference test $(P=0.05)$.
\end{tabular}


Table 2. 1997. Changes in percent cover, fresh weight, and dry biomass of dodder from infested cranberry vines prior to and following weed removal (raking) with a conventional bamboo hand rake $(\mathrm{N}=5) .^{2}$

\begin{tabular}{|c|c|c|c|c|}
\hline \multirow[b]{3}{*}{ Treatment } & \multicolumn{4}{|c|}{ Sampling date } \\
\hline & \multicolumn{2}{|c|}{27 July } & \multicolumn{2}{|c|}{8 Aug. } \\
\hline & Pre-raking & Post-raking & Pre-raking & Post-raking \\
\hline \multicolumn{5}{|c|}{ Weed cover (\%) } \\
\hline Zero removals & $44 \mathrm{a}$ & $44 \mathrm{a}$ & $59 \mathrm{a}$ & 59 a \\
\hline One removal & $53 \mathrm{a}$ & $14 \mathrm{ab}$ & $10 \mathrm{~b}$ & $10 \mathrm{~b}$ \\
\hline Two removals & $57 \mathrm{a}$ & $8 \mathrm{~b}$ & $16 \mathrm{~b}$ & $7 \mathrm{~b}$ \\
\hline$P$ & NS & 0.047 & $\leq 0.028$ & $\leq 0.009$ \\
\hline \multicolumn{5}{|c|}{ Fresh wt $\left(g \cdot m^{-2}\right)^{y}$} \\
\hline Zero removals & 252 & 252 & 303 & 303 \\
\hline One removal & 350 & 131 & 213 & 213 \\
\hline Two removals & 345 & 87 & 159 & 120 \\
\hline$P$ & NS & NS & NS & NS \\
\hline \multicolumn{5}{|c|}{$\operatorname{Dry} w t\left(g \cdot m^{-2}\right)$} \\
\hline Zero removals & 50.9 & 50.9 & 73.4 & 73.4 \\
\hline One removal & 62.5 & 27.6 & 57.5 & 57.5 \\
\hline Two removals & 53.8 & 18.4 & 44.6 & 32.2 \\
\hline$P$ & NS & NS & NS & NS \\
\hline
\end{tabular}

${ }^{2}$ Mean separation within column and measurement by Tukey's honestly significant difference test $(P=0.05)$. ${ }^{\mathrm{y}} 1 \mathrm{~g} \cdot \mathrm{m}^{-2}=0.0033 \mathrm{oz} / \mathrm{ft}^{2}$.

corresponding noninfested areas $(64 \%$ to $81 \%$ reduction).

The benefit of mechanical removal, in terms of dodder biomass reduction, was unclear. Removing dodder once per season reduced visual cover and a second weed removal did not give any additional benefit. Visual evaluation indicated that biomass was higher in control plots at the end of the summer, but actual harvested biomass values were similar for all treatments. The removal procedure may give the observer the impression that the canopy is more open, but hanging or broken dodder strands may be present that contribute substantially to actual biomass assessments.

The impact of mechanical removal on seed production is an important biological feature not addressed in this study. Other researchers performed dodder removal experiments on southeastern Massachusetts cranberry farms during Summer 1997 (Bewick et al., 1999). They examined the time of raking (mid-July and mid-August), number of treatments, and dodder seed production. They concluded that while raking reduced the number of dodder seeds set by $43 \%$ to $83 \%$ in two cranberry cultivars, 'Early Blacks' and 'Howes', the reduction in cranberry yield as a result of raking was significant enough to preclude recommending the practice except in very severe infestations. If dodder removal reduces dodder seed production and suppresses subsequent infestations, yield loss during the treatment years may be worth the long-term reduction in seed bank potential.

Yield reductions of $64 \%$ to $81 \%$ (dodder-infested areas compared to non-infested areas) measured in the present study (Table 3) fall within reported ranges for cranberry and certainly are of significant concern for growers (Bewick et al., 1988; Devlin and Deubert, 1980). Raking did not overcome the yield suppression commonly associated with dodder infestations and may result in additional yield reduction. Although one removal decreased yield only slightly compared to zero removals, two removals indicated a trend towards decreased yields; these findings were similar to reports by Bewick and Porter (1999). Yield loss is most likely related to the deleterious effects of the parasite (e.g., reduced light penetration, reduced available carbohydrates, etc.) rather than physical fruit abscission caused by the removal technique.

Individual mass per berry was similar from infested, mechanically removed, and non-infested areas (Table 3 ). Reduced competition among berries, because of lower numbers of fruit in the infested areas, could account for adequate size development despite nutrient loss to dodder. Cranberry plants produce fewer, but large (greater mass) fruit when flowers are selectively removed (Baumann and Eaton, 1986; Birrenkott and Stang, 1990). Although yield was reduced by dodder infestations, those berries produced were still of marketable size.

Although unconfirmed by standardized experimentation, we speculate that mechanical removal of dodder will not necessarily suppress infestations of dodder in the treated area in subsequent years. The dispersal of dodder seed is facilitated by many of the horticultural practices commonly utilized in cranberry production, such as water harvesting and application of sand (Sandler, 2001). Since dodder seed capsules are buoyant (Dawson et al., 1994; Parker and Riches, 1993 ) and water is used for a wide array of cranberry production activities, the locations of dodder infestations are difficult to predict and tend not to occur in the same area each year. We have observed that infestations often occur where the crop is removed from the production area during the water harvesting process, but infestations are not usually limited to these particular locations.

Many questions remain concerning the impact of dodder infestations and the removal techniques on the cranberry plant itself. We do not know exactly how dodder reduces cranberry yield (e.g., reduced light penetration, absorption of carbohydrates by the parasite at critical fruit development periods, reduced density of fruiting uprights, etc.). In addition, if mechanical removal of dodder causes cranberry leaf abscission, the timing of this control strategy may also be important since the timing of defoliation can affect carbon resource partitioning (Roper et al., 1992; Vanden Heuvel and Davenport, 2005). Research projects are being initiated to investigate some of these issues (H. Sandler and J. Vanden Heuvel, personal communication).

It is not known if vines that have had dodder removed will be more productive the following year. In any given year, a stand of cranberry vines is composed of an approximately equal mixture of vegetative and fruiting uprights (vertical stems) (Strik et al., 1991). Cranberry is biennial bearing, and research has shown that uprights that do not produce fruit in one year are more likely to be fruitful in the following year (Eaton, 1978; Roper et al., 1993). Of critical importance would be 

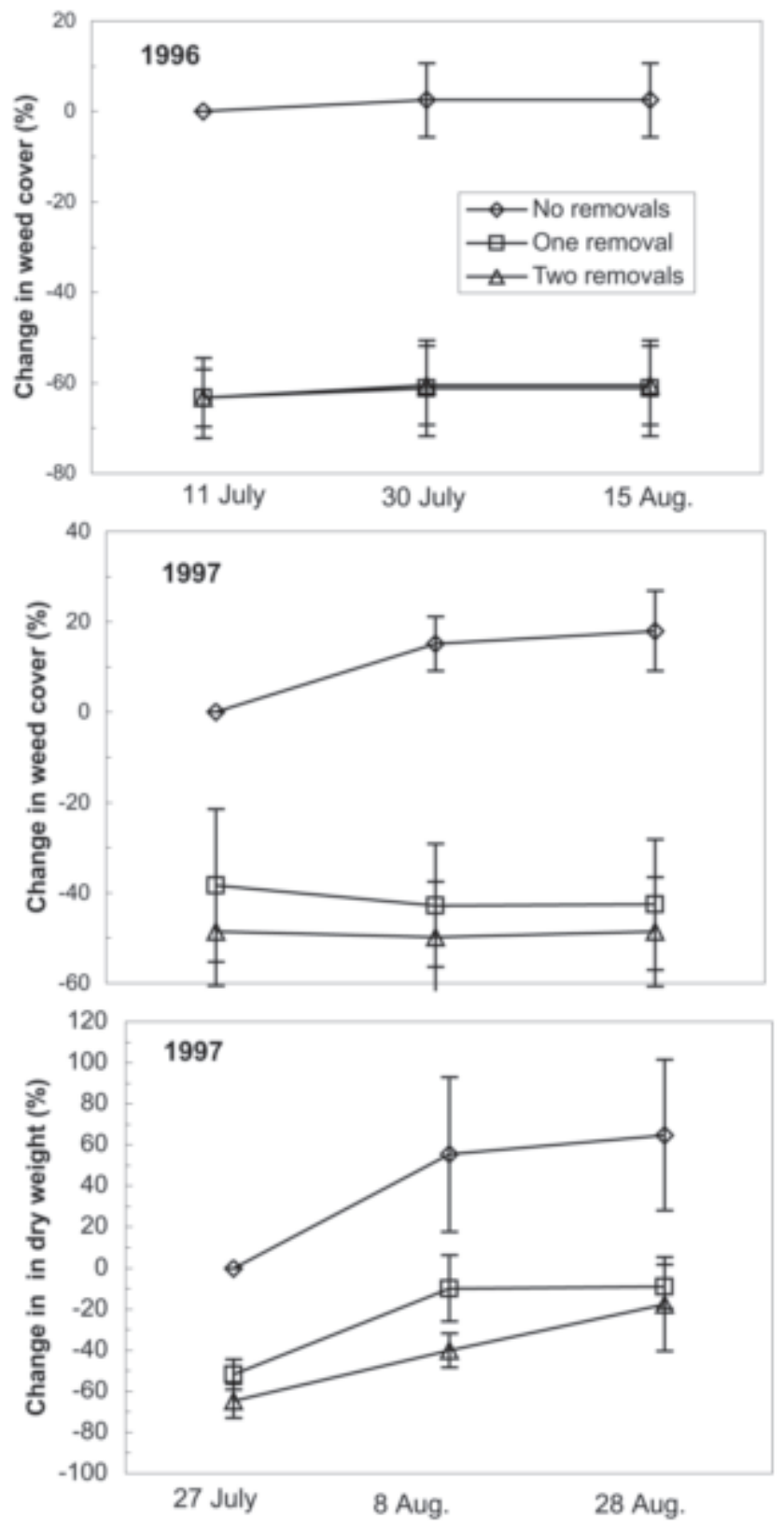

Fig. 1. Change in percent cover (1996 and 1997) and dry weight of dodder removed zero, one, or two times from infested cranberry vines over a 1-month period. Percent change was calculated by determining differences on the second and third sampling date compared to the baseline data (collected on the first date prior to removal) for each variable.

Table 3. 1997. Effect of mechanical weed removal of dodder on cranberry yield from infested plots and comparison to yield parameters from non-infested plots $(\mathrm{N}=5)^{\mathrm{z}}$.

\begin{tabular}{lrrc}
\hline & \multicolumn{3}{c}{ Yield $^{\mathbf{y}}$} \\
\cline { 2 - 4 } Treatment & $\left(\mathbf{t} \cdot \mathbf{h a}^{-1}\right)$ & $\left(\right.$ fruit $\left./ \mathrm{m}^{2}\right)$ & $(\mathrm{g} /$ berry $)$ \\
\hline Zero removals (infested) & $7.3 \mathrm{a}$ & $1177 \mathrm{a}$ & $0.78 \mathrm{a}$ \\
One removal (infested) & $6.4 \mathrm{a}$ & $1077 \mathrm{a}$ & $0.62 \mathrm{a}$ \\
Two removals (infested) & $3.9 \mathrm{a}$ & $622 \mathrm{a}$ & $0.58 \mathrm{a}$ \\
Zero removals (non-infested) & $20.5 \mathrm{~b}$ & $2930 \mathrm{~b}$ & $0.82 \mathrm{a}$
\end{tabular}

${ }^{2}$ Means separation within column by Tukey's honestly significant difference test $(P=0.05)$.

${ }^{y} 1 \mathrm{t} \cdot \mathrm{ha}^{-1}=0.4461$ ton/acre; 1 fruit $/ \mathrm{m}^{2}=0.0929$ fruit $/ \mathrm{ft}^{2} ; 1 \mathrm{~g}=0.0353 \mathrm{oz}$. the assessment of damage to the vegetative uprights during the mechanical removal treatment as these uprights would be more likely than flowering uprights to produce fruit the following year. Certainly, additional research is warranted to more fully understand the interactions of dodder, cranberry, and potential upright injury due to mechanical control methods.

Removing the dodder mat from the cranberry plants may allow for better fruit sizing and ripening by enhancing light penetration (Roper et al., 1995); however, color was not examined in this study. It has been determined that in temperate regions, embedded portions of dodder may be able to survive perennially (Dawson et al., 1984). It is not known if raking reduces the number or functionality of embedded haustorial connections, supporting some concerns about longterm benefits of mechanical dodder removal. The impact of mechanical removal of dodder on color development and retention of haustorial attachments could be areas for future research.

To maximize dodder control, growers should use multiple strategies that will maximize yield in the infested areas as well as reduce the dodder seedbank. Mechanical removal can be used as one possible option within the context of an integrated weed management program for dodder control (Sandler, 2005). Other strategies that can be combined with mechanical removal include novel postemergence options (Morrison et al., 2005) or the use of biological controls (Federal Register, 2005). Care should be taken not to introduce dodder seed during normal horticultural practices, such as sand application (Mason et al., 2006) or water harvesting activities. Mechanical removal may help to reduce the dodder seedbank potential for the following year. Although the mechanical removal of dodder cannot overcome the yield loss caused by the dodder infestation itself, fruit of marketable size were produced in the treated area.

\section{Literature cited}

Barbour, M.G., J.H. Burk, and W.D. Pitts. 1987. Methods of sampling the plant community, p. 182-208. In: Terrestrial plant ecology. Benjamin/Cummings Publ., Menlo Park, Calif.

Baumann, T.E. and G.W. Eaton. 1986. Competition among berries on the cran- 
berry upright. J. Amer. Soc. Hort. Sci. 111:869-872.

Bewick, T.A., L.K. Binning, and M.N. Dana. 1988. Post-attachment control of swamp dodder (Cuscuta gronovii) in cranberry (Vaccinium macrocarpon) and carrot (Daucus carota). Weed Technol. 2:166-169.

Bewick, T.A., L.K. Binning, and M.N. Dana. 1989. Control of swamp dodder in cranberry. HortScience 24:850.

Bewick, T.A., J.C. Porter, and D.M. Warrick. 1999. Raking is ineffective as a means of mechanical control of dodder (Cuscuta gronovii) in cranberry. Weed Sci. Soc. Amer. Abstr. 39:105.

Birrenkott, B.A. and E.J. Stang. 1990. Selective flower removal increases cranberry fruit set. HortScience 25:1226-1228.

Cudney, D.W., S.B. Orloff, and J.S. Reints. 1992. An integrated weed management procedure for the control of dodder (Cuscuta indecora) in alfalfa (Medicago sativa). Weed Technol. 6:603-606.

Dawson, J.H., F.M. Ashton, W.V. Welker, J.R. Frank, and G.A. Buchanan. 1984. Dodder and its control. U.S. Dept. Agr. Farmers' Bul., No. 2276.

Dawson, J.H., L.J. Musselman, P. Wolswinkel, and I. Dorr. 1994. Biology and control of Cuscuta. Rev. Weed Sci. 6:265-317.

Devlin, R.M. and K.H. Deubert. 1980. Control of swamp dodder (Cuscuta gronovii) on cranberry bogs with butralin. Proc. Northeast Weed Sci. Soc. 34:399-405.

Eaton, G.W. 1978. Floral induction and biennial bearing in the cranberry. Fruit Var. J. 32:58-60.
Else, M.J. 1990. Dodder and its control fact sheet. University of MassachusettsAmherst Cranberry Sta. Ext. Publ., East Wareham.

Else, M.J., H.A. Sandler, and S. Schluter. 1995. Weed mapping as a component of integrated pest management in cranberry production. HortTechnology 5:302-305

Federal Register. 2005. Alternaria destrucens, Strain 059. U.S. Environmental Protection Agency. 18 May 2005. <http:// a257.g.akamaitech.net/7/257/2422/ 0 l jan $20051800 /$ edocket.access.gpo. gov/2005/05-9903.htm>.

Mason, J., H.A. Sandler, and L.K. Hunsberger. 2006. Evaluation of sand stockpiles as potential sources of cranberry weeds. Weed Technol. 20(1): (In press.)

Morrison, J.R., H.A. Sandler, and L.K Romaneo. 2005. Management of swamp dodder (Cuscuta gronovii Willd.) in cranberry may be enhanced by the integration of a nontoxic household cleaner. Crop Protection 24:1-6.

Parker, C. and C.R. Riches. 1993. Parasitic weeds of the world-Biology and control. CAB Intl., Oxon, U.K.

Roper, T.R., J.S. Klueh, and M. Hagidimitriou. 1995. Shading timing and intensity influences fruit set and yield in cranberry. HortScience 30:525-527.

Roper, T.R., K.D. Patten, C.J. DeMoranville, J.R. Davenport, B.C. Strik, and A.P. Poole. 1993. Fruiting of cranberry uprights reduces fruiting the following year. HortScience 28:228.
Roper, T.R., E.J. Stang, and G.M. Hawker. 1992. Early season leaf removal reduces fruit set and size in cranberry. HortScience 27:75.

Sandler, H.A. 2001. Dodder fact sheet. Univ. of Massachusetts-Amherst Cranberry Sta. Ext. Publ., East Wareham.

Sandler, H.A. 2005. Weed management, p.18-32. In: M.M. Sylvia and D. Cannon (eds.). Cranberry chart book-Management guide for Massachusetts. Univ. of Massachusetts-Amherst Cranberry Sta. Ext. Publ., East Wareham.

Sandler, H.A., M.J. Else, and M. Sutherland. 1997. Application of sand for inhibition of swamp dodder (Cuscuta gronovii) seedling emergence and survival on cranberry (Vaccinium macrocarpon) bogs. Weed Technol. 11:318-323.

Sandler, H.A. and J. Mason. 2004. Efficacy of flooding for the control of dodder (Cuscuta gronovii) and several broadleaf species in commercial cranberry production in southeastern Massachusetts: A two-year study. Proc. Northeast Weed Sci. Soc. 58:163. (Abstr.)

Strik, B.C., T.R. Roper, C.J. DeMoranville, J.R. Davenport, and A.P. Poole. 1991. Cultivar and growing region influence return bloom in cranberry uprights. HortScience 26:1366-1367.

Vanden Heuvel, J.E. and J.R. Davenport. 2005. Effects of light, temperature, defoliation, and fruiting on carbon assimilation and partitioning in potted cranberry. HortScience 40:1699-1704. 